\title{
Pathways toward a positive future
}

\author{
Examples of emerging sustainable living practices \\ can be found in all parts of the world. However, \\ negative impacts from production and consump- \\ tion remain and broad shifts toward sustainable \\ lifestyles are not yet occurring. How can future \\ scenarios and road mapping be used to develop \\ actions to support the transition toward sustain- \\ able living? By Rosa Groezinger, Rosanne Verbree, \\ Cheryl Hicks and Maria Ritola
}

\section{Introduction}

Since the mid-1980s Europe has calculated an "overshoot day" which is the point in the year when "our resource consumption for a given year exceeds what the planet can provide for an entire year" (Global Footprint Network, 2008). Since 1986 when overshoot day fell on December 31, resource consumption in Europe has accelerated to a point where overshoot day fell on August 22 in the year 2012 (Global Footprint Network 2012). According to United Nations Development Programme (UNDP 2010), our unsustainable consumption and production patterns present major challenges to the development of a sustainable economy. Research findings indicate that the main elements of production and consumption that affect lifestyle-related environmental impacts are food, mobility and housing (EEA 2010a).

Between January 2011 and December 2012, the SPREAD Sustainable Lifestyles 2050 Social Platform Project (hereafter referred to as the "SPREAD project") sought to identify the key obstacles to sustainable living in Europe and the potential to overcome these challenges [1]. The project received funding under the European Commission Seventh Framework Programme: Socio-economic Sciences and Humanities research grant program. Business leaders, researchers, policy makers, and civil society stakeholders participated in the SPREAD project to collectively develop a vision for sustainable lifestyles in 2050. Four scenarios for sustainable living in 2050 were developed within the project [2]. An accompanying roadmap was developed with recommendations for how different key actors can contribute toward achieving the scenarios [3].

This article outlines examples of current unsustainable consumption and production patterns, but the primary focus will be on the opportunities that exist to overcome obstacles to sustainable living. We provide background and outcomes from the
SPREAD project and four future sustainable lifestyle scenarios, and outline a roadmap toward sustainable lifestyles in Europe from the present day to the year 2050 .

\section{Framing the problem}

Numerous scholars have published research findings on the sustainability impacts of modern European lifestyles. Selected examples include:

- Tukker and Huppes (2006) concluded that in total the final consumption of food and drink, private transportation and housing are the source of some 70 to 80 percent of Europe's total environmental impact.

- Meat and dairy consumption alone have been identified as being responsible for almost one quarter (24 percent) of final consumption impacts (Weidema et al. 2008) and are the largest share in the food and drink category.

- 40 percent of Europe's total energy consumption is consumed in domestic space heating, water consumption, appliances and electronics with space heating alone accounting for fully 67 percent of household energy consumption in the EU27 (EEA 2010b).

I In 2011, the World Health Organization (WHO) stated that in the EU27 some 60 percent of adults and over 20 percent of school age children are overweight or obese. The single most common cause of death in Europe is coronary heart diseases (CHD), which is often associated with tobacco use and consumption of fatty foods.

Considering the above lifestyle related impacts in light of a global population that has doubled since the 1960s and with projections for continued growth for the coming decades (Worldbank 2012), this leads to sobering conclusions respecting the environmental impacts of future consumption and production. What can be done in the face of these growing challenges? Environmental policy lately has focused primarily on environmental impacts from consumption and production and on technological solutions. Lifestyle is a major driver of sustainability impacts. How and why people choose certain lifestyles is not well understood and encouraging sustainable choices has not been addressed in a serious way by policy makers. Alternative concepts of how future sustainable lifestyles and societies might look, and the related social and technical innovation that is required are also missing. The SPREAD project aimed to fill these gaps by developing a range of scenarios and pathways to the year 2050. The following section explains the methodology employed within the SPREAD project. 


\section{Creating Scenarios}

The starting point for the project was to identify a sustainable level of resource consumption and the aspects of European lifestyles that drive the resource consumption related impacts. To perform this calculation, the SPREAD project applied a material footprint methodology to model the resource consumption of a given lifestyle (e.g. in the areas of consumption, mobility and housing) and defined a sustainable annual material footprint as being 8,000 kilogram per capita in 2050 [4]. This material footprint represents a rough approximation of the ecological limit that can be sustainably supported. Considering that the average annual material footprint of Europeans today is estimated as being between 27,000 and 40,000 per capita (SPREAD Consortium 2012a) a considerable material footprint reduction is necessary to achieve the annual 8,000 kilogram/capita goal by 2050 .

\subsection{The backcasting method}

How can this goal be reached? To explore the diverse pathways for potential sustainable lifestyles, the SPREAD project developed four scenarios for the evolution of sustainable lifestyles by the year 2050. Further, the scenarios demonstrate how current harmful environmental and social impacts from European lifestyles can be overcome. Importantly, a scenario is not intended to be a predication or forecast, but rather the aim is to explore the most extreme possibilities of a given development pathway (SPREAD Consortium 2012b). New ways of considering how daily life might be lived are presented to engage stakeholders and to stimulate dialogue around alternative futures (SPREAD Consortium 2011).

It is worth noting that the scenarios are intended to present the most extreme possible circumstances and for this reason some of the elements might at first appear improbable. To develop the sustainable lifestyle scenarios the project consortium applied a backcasting methodology. Sustainable lifestyles were set as a goal and the differences between the current reality and the desired future were clarified to identify the areas where the greatest changes are required (see figure 1 and 2 for a schematic overview of the backcasting exercise).

The backcasting methodology was applied to explore alternative pathways to reach the desired future goals while overcoming the risk that taking the present as the start point may lead to concentrating on challenges that are not relevant to the desired future we aim to achieve. The SPREAD project further considered a number of external factors and limitations when developing the scenarios as potential limiting factors for meaningful future living. An example of such an external factor is the anticipated future scarcity of crude oil that will force production to decline at some point (peak oil).

\subsection{Process steps}

The development of the future scenarios for more sustainable lifestyles in 2050 built on previous work undertaken within the SPREAD project. This work includes the identification of the most critical lifestyle impacts, and the barriers and drivers for change. Using the identified lifestyle impacts as a starting point, and combining the outcome of a selective Delphi Survey that asked survey respondents to describe things they value in a future sustainable lifestyle, a scenario framework was defined [5]. Technology as either pandemic or endemic, and society's governing principle as either human centric or meritocratic were identified as critical uncertainties.

I In a pandemic technology, there are a few dominant technologies for any task or human need, such as technologies for building construction, transportation, energy production, and communication. Between these technologies, there is fierce competition in global markets.

I In an endemic technology, the focus is at the local level. Tools, infrastructure and solutions are developed and grown locally, and local living conditions dominate over technology, e.g. where there is wood houses are built of timber. The economy is driven by efficiency and innovation is driven by thinking and acting locally.

- A human-centric society is about the use of human capital in all its forms. Skills are valued, and the success of society depends on everyone contributing and on everyone's ability to be good citizens, family members, neighbours and professionals. There is some division of labour, but self-improvement through leisure is also appreciated.

I A meritocratic society circles around professional skills. People with the most commercially valuable professional skills are the engines of the economy and paid accordingly. There is extreme division of labour: you do only what you are very good at. Policies and structures are developed to facilitate the work of the leading industries and professions.

These two sets of alternatives formed the scenario quadrants, and with these quadrants four possible future landscapes were created (figure 3). The uncertainties defined the main drivers that shaped the scenarios and formed the basis for a backcast-

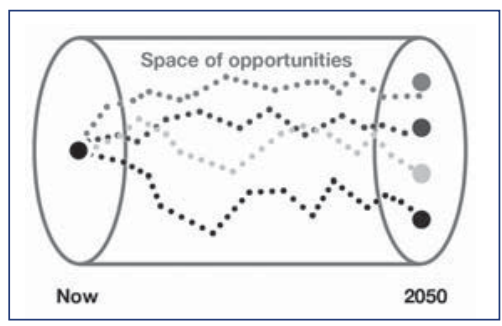

Figure 1: Usual future perspective: Cylinder model to construct possible future scenarios (SPREAD Consortium 2012b: 7)

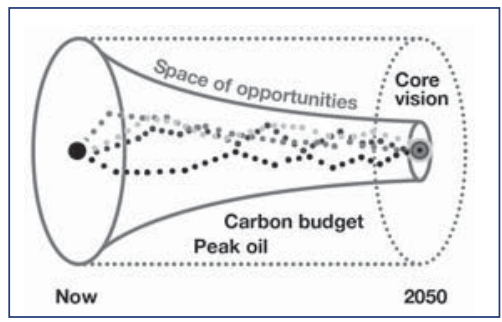

Figure 2: Future perspective with system boundaries: Cone model to construct meaningful future scenarios (SPREAD Consortium 2012b: 7). 
ing workshop that was held November 24-25, 2011 in Tuusula, Finland. During the workshop four alternative scenario pathways from 2012 to 2050 were created with the help of 54 participants from 16 countries, representing different stakeholder groups. Participants "counted backwards" from 2050 to today by asking "What things need to happen in 2040, 2025, and 2015 to reach the different lifestyle outcomes to living within the 8,000 kilogram material limitation?” A special focus was given to food, mobility, housing and health, as well as on the drivers of different lifestyle choices. The following assumptions about technology and lifestyle patterns were made for all scenarios:

I Virtually zero-emission electricity production,

- Radical reduction of energy required for heating and cooling of new and existing buildings,

- Decreased need for mobility and radically reduced levels of private car use,

- Reduced consumption of meat.

Following the Finland workshop, a second Delphi Survey with stakeholders and experts was undertaken with the aim of gathering additional assumptions and arguments for each scenario. The survey results were included in a draft of the scenarios. This draft was further tested and quantified in the SPREAD People's Forum, which was held to explore the scenarios with "real people" from across Europe [6]. In the final project phase the scenarios were advanced to form final stories and visualizations. Further focus was placed on defining the life experience of different people in each scenario and the expected impact of environmental and social changes.

The four scenarios aimed to demonstrate how various situational and behavioural factors contribute to the development of sustainable lifestyles for people across Europe. Ways in which promising niche strategies with potential to reduce overall environmental stressors could grow into widely adopted mainstream practice were identified. Figure 3 provides an overview of the four different scenarios.

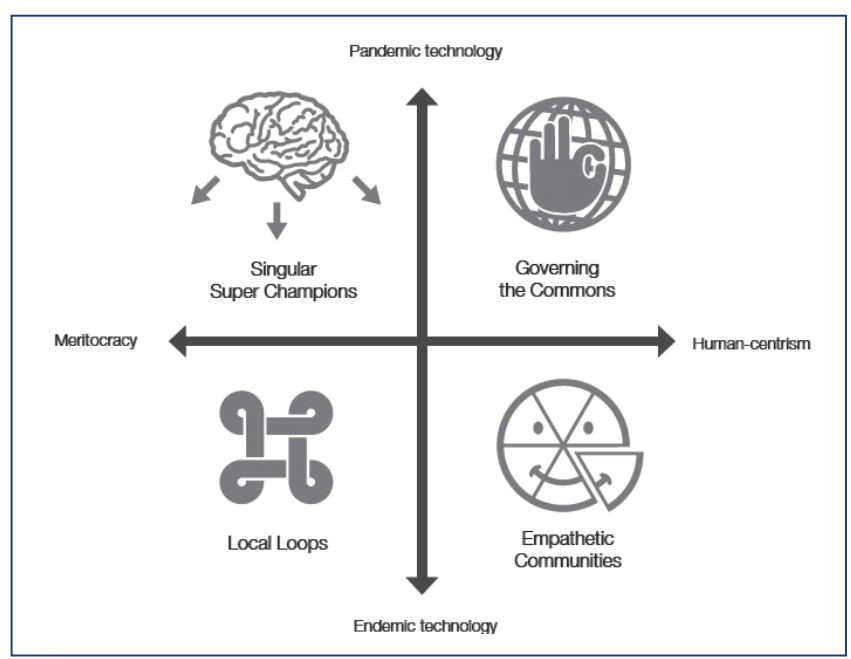

Figure 3: The four scenarios (SPREAD Consortium 2012b: 11)

\subsection{Resulting roadmap}

After building the 2050 sustainable living scenarios the project team turned their efforts toward creating a roadmap to reach the scenarios. During two stakeholder workshops with representatives from a range of different fields and 13 additional expert meetings, key steps from today to 2050 were identified and compiled into a roadmap. Pathways to make these changes a reality were identified for four key enablers: policy and governance; the economy and the monetary system; social innovation; and individual behaviour change. Each pathway outlines opportunity spaces for policy makers and for the relevant stakeholder groups to overcome existing barriers and lock-in effects that lie behind unsustainable living. In this article the main focus will be on the economic enabler [7].

Overarching economic principles that are necessary for a transition from the 2012 situation towards sustainable living in 2050 include:

- A Sustainable Economy Commission will ensure systematic policies and "beyond Gross Domestic Product" indicators that stimulate well-being, equity and healthy lifestyles.

- A transition from a "debt-based economy" to a "commonsbased economy" will take place where the monetary system is fully linked with our ecological capital.

- A new economy will arise that encourages savings to fund long-term investments in sustainable economic sectors and innovation for sustainable living.

I Finally, there will be alternative economies, currencies, and new business models that support sustainable living.

\section{The outcomes: scenarios and the economic pathways}

Four scenarios for sustainable living in 2050 were developed during the SPREAD project. This article describes the Governing the Commons and the Local Loops scenarios and potential economic pathways to reach these future scenarios. These economic pathways are modifications from the roadmap that was developed in multi-stakeholder-dialogues to the previously created scenarios.

\subsection{The Governing the Commons future scenario}

The Governing the Commons scenario is situated in the upper right corner of figure 3 , and is a combination of a pandemic technology and a human-centric society. This scenario is mostly a digital reality that helps people to break free from many cultural constraints, enables an intelligent use of resources and at the same time directs people's attention and behaviour away from material consumption toward digital interaction, and thus toward greater sustainability.

Under the Governing the Commons scenario an important element and driver is the 3D printer, which made it possible for people to control their own production and consumption. First, the $3 \mathrm{D}$ technology was seen as a niche invention; however, by 2030 it had altered lifestyles and businesses. In the latter half 
of the $21^{\text {st }}$ century, the drivers behind mass consumption are replaced by a culture of "self-creation" which is assisted by 3D printers and similar tools. Endless possibilities to shape and re-create one's identity are offered and people become more aware of what belongs to them. Developing new skills and a do-it-yourself ethic became easy with access to information, the digitally assisted training tools, peer support and the use of billions of microchips embedded in machines, walls and streets that bring new types of data to users. Social networks continue to grow and the institutions that lack online networks will vanish for many people.

Employment will take the form of multi-profession self-employed individuals; a peer-to-peer (P2P) service economy will replace big corporations. "Interest networks", combing policy with doing things gradually, will grow and replace traditional political parties. New modes of collaboration and tools will result in new political agendas that are closer to peoples' daily lives: "Wikidemocracy". This democracy has a new trust in politics and its capability of changing society toward positive social change. The most important aspects for the Governing the Commons scenario are presented in table 1.

\subsection{Economic Enabler for Governing the Commons}

The role of economy in this scenario is first to overcome the current debt-based monetary system. In the Governing the Commons scenario the debt-based monetary system is replaced with a commons-based economy by 2050 on the basis of a Europe-wide plan to accomplish this change. The new economic model is based on savings (vs. debt) to fund long-term investment. European households begin to increase their savings and reduce their borrowing. Responsible lending institutions proliferate, and peer-to-peer structures are formalized.

A second pathway describes a shift toward a system where consumers control their own production and where the peerto-peer service economy has disrupted the globalized world of multinational corporations. Steps toward this reality are European policy support for cooperative movements across the continent and policies that stimulate social entrepreneurship. Regional and locally focused companies become competitive with the large multi-nationals.

The final pathway describes a shift toward sustainable living being valued in all fields. New collaboration tools enable innovative alternative business models that connect big business with social entrepreneurs to foster sustainable lifestyle solutions (that is a mix of profit/not-for-profit, public/private, individual/collective). Access to goods and services is supported and there are effective incentives for alternatives to ownership including cradle-to-cradle business models that connect production to consumption, and new technologies that enable sustainable communities, the DIY manufacturing model being a great example. This same pathway is also applicable to the Local Loops scenario which will result in production systems at the more local and regional level. The Local Loops scenario is described next.

\subsection{The future scenario of Local Loops}

The Local Loops scenario is situated in the lower left hand corner and is a combination of endemic technology and a meritocratic society. "Local Loops" is a technical concept that refers to local and regional production cycles. In the Local Loops scenario, the lives of people and their ways of belonging are built around their work. New kinds of professions emerge as a re-

\begin{tabular}{|c|c|}
\hline Education & $\begin{array}{l}\text { The main focus in education is on peer-to-peer skill } \\
\text { sharing, and learning by doing. The emphasis is on } \\
\text { informal education without classrooms. Pandemic } \\
\text { technology accelerates the knowledge sharing. }\end{array}$ \\
\hline Work & $\begin{array}{l}\text { The use of skills is important, but it causes fragmen- } \\
\text { tation of people's sources of income. Micro-tasks, } \\
\text { crowdsourcing and being useful to your peers are } \\
\text { keywords. }\end{array}$ \\
\hline City & $\begin{array}{l}\text { The cities are based on existing infrastructure, but } \\
\text { their experiences are improved. Office and school } \\
\text { buildings are not used for their original purposes and } \\
\text { are converted into flats and public spaces. }\end{array}$ \\
\hline Health & $\begin{array}{l}\text { Different ways of healthy living have become the } \\
\text { norm. The use of digital feedback and P2P network } \\
\text { support are an important contribution for health } \\
\text { care. There is public funding provided for health-care } \\
\text { cooperatives. }\end{array}$ \\
\hline Living & $\begin{array}{l}\text { People live in small flats and work in new offices. } \\
\text { The digital era is key to providing people with quality } \\
\text { in their lives: smart homes and digital services are } \\
\text { common. }\end{array}$ \\
\hline Food & $\begin{array}{l}\text { The production and distribution of food is managed } \\
\text { by global food systems, offering a wide variety of } \\
\text { diets, and reducing the intake of energy. New food } \\
\text { options include vegetable choices and synthetic } \\
\text { meats. }\end{array}$ \\
\hline Mobility & $\begin{array}{l}\text { The use of digital tools has greatly reduced mobility. } \\
\text { Commuting is minimized and the construction of } \\
\text { new traffic infrastructure has become unnecessary. } \\
\text { Car and ride sharing and smart public transit are } \\
\text { the main forms of transportation. }\end{array}$ \\
\hline Consuming & $\begin{array}{l}\text { The 3D printer-based personalized consumption. } \\
\text { Material consumption is dramatically reduced be- } \\
\text { cause of do-it-yourself (DIY) repair and products up- } \\
\text { grading. New designs and producer cultures are } \\
\text { formed by high degrees of appliance personalization, } \\
\text { virtual consumption and recyclable generic materi- } \\
\text { als, helping to reduce the overall number of house- } \\
\text { hold appliances. }\end{array}$ \\
\hline Economy & $\begin{array}{l}\text { The economic organization is characterized by micro- } \\
\text { tasks. Open source, open data and free information } \\
\text { distribution are the drivers for new innovation and } \\
\text { the new economy is known by personal optimization, } \\
\text { DIY, peer services and manufacturing. }\end{array}$ \\
\hline Sense of security & $\begin{array}{l}\text { Peer-to-peer communities create a sense of security. } \\
\text { Equality and empowerment is promoted by ease of } \\
\text { access to services, products and a global knowledge } \\
\text { base. Personalized appliances and direct participa- } \\
\text { tion impart a sense of belonging and security. }\end{array}$ \\
\hline Leisure Time & $\begin{array}{l}\text { Leisure time is formed around digital interactions, } \\
\text { home consumption, and high quality household ca- } \\
\text { pabilities. }\end{array}$ \\
\hline
\end{tabular}

Table 1: Most important aspects for the Governing the Commons scenario 
sult of locally adapted technology. New models of craftsmanship and professional communities shape the way people live, work and spend their free time.

The Local Loops scenario is built around oil scarcity and a radical energy crisis that causes a rise in resource prices. Societies are forced to re-evaluate their foundations and notions of well-being. Most companies, politicians and citizens are ill pre-

\begin{tabular}{|c|c|}
\hline Education & $\begin{array}{l}\text { Transmitting and sharing skills are important. Crafts- } \\
\text { manship and specialization are stimulated by mutual } \\
\text { teaching and problem-based learning. }\end{array}$ \\
\hline Work & $\begin{array}{l}\text { Guilds are of significant importance in the working } \\
\text { area. They stimulate engagement with issues and } \\
\text { collaboration within and among guilds. Needs } \\
\text { are met by applying design thinking and formulating } \\
\text { local solutions. }\end{array}$ \\
\hline City & $\begin{array}{l}\text { Each city has multiple urban centres that are formed } \\
\text { around their own loops. Guilds are an important } \\
\text { basic element in each loop. }\end{array}$ \\
\hline Health & $\begin{array}{l}\text { Working spaces provide medical care. Basic rights } \\
\text { apply for all regions and health care is protected as } \\
\text { a priority. }\end{array}$ \\
\hline Living & $\begin{array}{l}\text { Shared spaces, existing infrastructure and co-working } \\
\text { spaces characterize life in the local loops. Members } \\
\text { of the guild often live in the same neighbourhood. }\end{array}$ \\
\hline Food & $\begin{array}{l}\text { Food production and distribution are mainly local and } \\
\text { transportation needs have been minimized with food } \\
\text { distribution/retail in each neighbourhood. The use of } \\
\text { energy for food production is optimized. }\end{array}$ \\
\hline Mobility & $\begin{array}{l}\text { The main modes of transportation are walking and } \\
\text { cycling. Existing infrastructure is optimized and ser- } \\
\text { vices are home-delivered. People favour local tourism } \\
\text { and long vacations. }\end{array}$ \\
\hline Consumption & $\begin{array}{l}\text { New products are made with high-quality local mate- } \\
\text { rials and design and virtually all products are repair- } \\
\text { able. The availability of foreign goods is low. The over- } \\
\text { all volume of appliances needed is reduced through } \\
\text { sharing schemes and replacement services. }\end{array}$ \\
\hline
\end{tabular}

Economy Local user-centric adaptations and efficient local clustering characterize the Local Loops economy.

\begin{tabular}{ll}
\hline Sense of security & $\begin{array}{l}\text { A sense of security is generated as a result of the } \\
\text { guilds and the understanding of how the closed cycle } \\
\text { system functions. Most people identify themselves } \\
\text { as part of their work communities. }\end{array}$ \\
\hline Leisure time & $\begin{array}{l}\text { Housework is mainly outsourced so people are able } \\
\text { to maximize their inputs toward their work commu- } \\
\text { nities. Leisure time is mostly spent with guild mem- } \\
\text { bers. }\end{array}$ \\
\hline
\end{tabular}

Table 2: Most important aspects for the Local Loops scenario pared for the crisis. Logistics becomes more expensive causing a shift towards local production. Citizens gather to force several European states and the EU to launch new programmes to re-define policy structures that recognise the resource constrained reality. New programmes are based on "local resource loops", referring to regions that are self-sufficient at a local scale in terms of key resources, and are based on ideas such as transition towns and eco-villages. In the loops, people are dependent on each other's skills.

Scientific expertise dominates global structures in the Local Loops scenario. However, the emphasis of many businesses and professions is on user-centred design that produces smart and creative local adaptations. Global networks are still important, but local production and culture increase in value. Foreign products become less appealing to the average consumer. Each loop has their own influential professional groups, the "guilds", who form the core of local innovation systems and competitiveness. These guilds also influence policy making toward a more local level. The most important aspects for the Local Loops scenario are presented in table 2.

\subsection{Economic enabler for Local Loops}

The economy is again a key enabler of the Local Loops scenario. One of the pathways, concerning new business models that support sustainable living under the Local Loops scenario, is described above. The remaining two pathways for Local Loops are described below.

The first economic enabler addresses the current unbalanced distribution of labour. There are widening gaps between the employed and the unemployed. The desirable future situation is one in which there is both a meritocratic system but also a more equal distribution of income across different job categories. The gap between the lowest and highest salary ranges is capped at a factor of ten. Labour market reforms reduce working hours to enable a focus on quality of life and this focus is broadly promoted as a socially desirable goal. Employment, creativity and growth in alternative currencies are stimulated.

The final pathway concerns the current focus on GDP in growth-based economies, which does not consider external costs or impacts on the environment or society. This focus shifts toward a situation where environmental and societal externalities are fully internalized into the economic system. Rethinking the GDP-based measurement tool to include the external costs and the provision of the necessary legal framework is the first step. In the end, the increase in logistics costs stimulates a focus on local production and local resources.

\section{Conclusion}

The article gave an overview of potential future sustainable living scenarios in the year 2050 and illustrated the role that economic structures play in supporting and developing such futures. This article has also demonstrated how the tools of scenario building and road mapping can be used to illustrate 
the changes in the function of the economic system that will be required to reach a sustainable and desirable future. Essential elements of these changes include the internalization of environmental and social externalities to shift consumption and production toward sustainable alternatives, the shift from debt as the basis of our economic system toward a savings based economy, and a shift from GDP to different measures of welfare. Furthermore, future businesses need to be based on new and innovative business models with sustainability at their core.

As the European economic and financial crisis continues, and as the future structure of our economy is presently being decided, there is a pressing need to consider the pathways described above as alternatives if we are to avoid locking ourselves into an economic system preserves an unsustainable businessas-usual model for decades to come.

\section{Annotations}

[1] The SPREAD project was led by the Collaborating Centre on Sustainable Consumption and Production (CSCP), Wuppertal, Germany. Project consortium partners were: The Northern Alliance for Sustainability (ANPED), Belgium; Ashoka, France; Demos Helsinki, Finland; the Energy Research Centre of the Netherlands (ECN), The Netherlands; Ecoinstitut Barcelona (ECOI), Spain; EuroHealthNet, Belgium; Politecnico di Milano (Polimi), Italy; Regional Environmental Center for CEE countries (REC), Hungary; and The International Institute for Industrial Environmental Economics at Lund University (ULUND), Sweden. Find more information on the project's website: http://www.sustainable-lifestyles.eu/.

[2] The scenarios were developed by Juha Leppänen, Aleksi Neuvonen and Maria Ritola from Demos Helsinki.

[3] The roadmap was developed by Leida Rijnhout and Sylvia Lorek from the Northern Alliance for Sustainability (ANPED) together with the CSCP.

[4] For more information on the method behind the material footprint read: Lettenmeier et al. 2011; Kotakorpi et al. 2008; Bringezu 2009 and SPREAD Consortium 2012a

[5] For more information: SPREAD Consortium 2012b.

[6] For more information on the People's Forum read SPREAD Consortium 2012a; Verbree et al. 2013.

[7] For more information on the (other) enablers read: SPREAD Consortium 2012c or SPREAD Consortium 2012d.

\section{References}

Bringezu, S. (2009): Visions of a sustainable resource use. In: Bringezu, S./ Bleischwitz, R. (Eds.) (2009): Sustainable resource management: Global trends, visions and policies. Greenleaf publishing, Sheffield, S. 155-215.

EEA (2010a): The European environment - state and outlook 2010: synthesis. European Environment Agency, Copenhagen.

EEA (2010b): ENER22 Energy efficiency and energy consumption in the household sector. Available online on 19th April 2013. http://eea.eionet. europa.eu/Public/irc/eionetcircle/energy/library?l=/workshops/eionet_ worksop_10-11/eehouseholdspdf/_EN_1.0_\&a=d.

Global Footprint Network (2008): Earth overshoot day 2008. Today is Earth Overshoot day: the day our demand surpasses nature's budget. Available online on $5^{\text {th }}$ June 2013. http://www.footprintnetwork.org/en/index.php/ newsletter/det/today_is_earth_overshoot_day_the_day_our_demand_ surpasses_natures_budget.

Global Footprint Network (2012): Earth overshoot day 2012. Today is Earth Overshoot day: the day our demand surpasses nature's budget. Available online on 27 $7^{\text {th }}$ May 2013. http://www.footprintnetwork.org/en/index.php/ newsletter/det/today_is_earth_overshoot_day_the_day_our_demand_ surpasses_natures_budget.
Kotakorpi, E. / Lähteenoja, S. / Lettenmeier, M. (2008): Household Mips Natural resource consumption of Finnish households and its reduction. The Finnish Environment 43en/2008. Finnish Ministry of the Environment, Helsinki.

Lettenmeier, M. / Lähteenoja, S. / Hirvilammi, T. / Laakso, S. / Aalto, K. (2011): Material Footprint of low-income households in Finland - Consequences for the sustainability debate. In: Sustainability 4/2012, S. 1426-1447.

SPREAD Consortium (2011): Sustainable lifestyles: today's facts \& tomorrow's trends. D1.1 sustainable lifestyles baseline report.

SPREAD Consortium (2012a): iFuture - The diversity of sustainable lifestyles. Nov. 2012.

SPREAD Consortium (2012b): Scenarios for Sustainable Lifestyles 2050: From Global Champions to Local Loops.

SPREAD Consortium (2012c): EU Sustainable Lifestyles Roadmap and Action plan 2050. Pathways for enabling social innovation and behaviour change.

SPREAD Consortium (2012d): SPREAD Roadmap Timeline.

Tukker, A. / Huppes, G., et al. (2006): Environmental Impact of Products (EIPRO): Analysis of the life cycle environmental impacts related to the final consumption of the EU25. Seville, JRC/IPTS/ESTO: 139.

UNDP (2010): The real wealth of nations: Pathways to human development. Human Development Report 2010. 20 th anniversary edition. Available online on 25th April 2013. http://hdr.undp.org/en/reports/global/hdr2010/ chapters/.

Verbree, R. / Groezinger, R. / Hicks, C. / Kuhndt, M. / Kuittinen, O. (2013). Sustainable lifestyles. From today's realities to future solutions. Manuscript submitted for publication. In: Journal of Cleaner Production.

Wesnæs, M. / Hermansen, J. / Kristensen, T. / Halberg, N. (2008): Environmental Improvement Potentials of Meat and Dairy Products, In: Eder, P./ Delgado, L. (Eds.): JRC Scientific and technical reports.

WHO (2011): Obesity and overweight, Fact sheet N³11, Updated March 2011. Available online on 22th April 2013. http://www.who.int/mediacentre/ factsheets/fs311/en/.

Worldbank (2012): World Population Growth. Available online on 29th of April 2013. http://www.worldbank.org/depweb/beyond/beyondco/ beg_03.pdf.

\section{AUTHORS + CONTACT}

Rosa Groezinger is project manager, Rosanne Verbree is project assistant and Cheryl Hicks is team leader at the Collaborating Centre on Sustainable Consumption and Production (CSCP).

Collaborating Centre on Sustainable Consumption and Production, Hagenauer Strasse 30, 42107 Wuppertal, Germany. E-Mail: rosa.groezinger@scp-centre.org, rosanne.verbree@scp-centre.org, cheryl.hicks@scp-centre.org

Maria Ritola is researcher at Demos Helsinki.

Demos Helsinki, Laivurinkatu 41, kulmahuoneisto, 00150 Helsinki, Finland. E-Mail: maria.ritola@demoshelsinki.fi
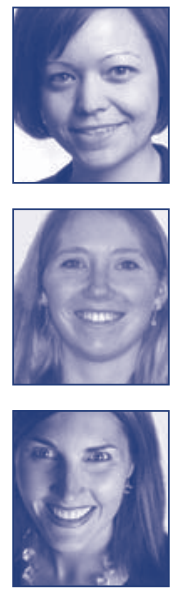
Copyright (C) 2013, IÖW und oekom Verlag. Die Nutzung des Artikels ist Abonnenten von Ökologisches Wirtschaften vorbehalten. Nachdruck und Vervielfältigung des Artikels einschließlich Speicherung und Nutzung auf optischen und elektronischen Datenträgern nur mit Zustimmung der Redaktion von Ökologisches Wirtschaften (http://www.oekologischeswirtschaften.de). 